\title{
Political Repression: A Comparative Study
}

\section{Ahmed Jasim}

English Department, College of Education for Human Sciences, University of Babylon, Iraq.

\begin{abstract}
This paper analyzes the differences as well as similarities between Pinter's "One for the Road" and Abd Sabur's "Night Traveller" that deal with the theme of suppression within the critical framework of the "Theatre of the Absurd". I argue in my present research that the two plays named above are necessarily oppressive, enriched with an oppressor-oppressed dynamic. In such cases, the suppressor uses all available resources to keep the oppressed quiet. Nonetheless, if both plays are viewed through a "theatre of the Oppressed", then they may be able to revolt Against Systematic suppression.
\end{abstract}

Keywords-oppression, Theatre of the Absurd, oppressor, oppressed, psychological, political.

\section{INTRODUCTION}

Since oppressive regimes are now recreating themselves in the form of different practices, art possesses a crucial power, allowing the masses to resist such regimes. This is especially true to the field of theatre productions. Although a theatrical performance is often used as a form of entertainment, it can also be applied to encourage resistance or to document and criticize a community or communal event. Various works including Pinter's one for the Road and Salih's Night Traveller use a theatrical political platform to explore oppression, which can even sometimes motivate oppressed audience members to engage in resistance activities instead of merely falling to submission. It is often through such plays that they are given the power to initiate positive changes.

\section{Oppressive perspective:}

Although suppression is naturally immoral and destructive, it is important to study the psychology of oppressors. Through this, we are afforded a deep insight into the mindset and characteristics of the oppressors, and this can ultimately allow for the empowerment of the oppressed. Wendell points out that oppressors primary objective is to use their power to quash the hopes and dreams of the oppressed, as she states "oppression reaches into our psyches and undermines our ability and our very desire to oppose it. It can blind us to the choices that remain to us and to our own strength to make them" (Bushnell 1995, 44). The actions used by oppressors to silence their victims are external political and can ultimately cause psychologicaloppression. Such strategies allow the playwright to show oppressors thoughts through the physical treatment of his subjects, as well as indicating what the suppressor is hoping to achieve. Meaning that such a destructive effect is only possible if specific external factors are involved, which influence the minds of the oppressed both directly and indirectly. Wendell (1990) explores these abuse practices "Seeking causes of oppressive actions and situations in those who are oppressed by them is often called 'blaming the victim'. It does not necessarily involve blaming or even assigning responsibility to victims. It does focus attention on characteristics of the victims and away from other people's responsibilities, such as the oppressive actions of individuals who are harming them or the more general social causes of the victims' oppression, including institutions, laws, or economic conditions"(20).

This gives the suppressor complete power to enjoy witnessing the suffering and ignorance of their victims. The suppressor is very much aware that the oppressed will do or believe anything to please those in possession of power. Moreover, if the oppressed rebel against the authority, they may be subjected to torture, arrest and other actions aimed at depleting their moral and destroying their identity(Prilleltensky and Gonick 2007, 127). This nodal point is applicable to literary characters. When creating Nicholas, and ambiguous political investigator who resorts to a number of interrogation techniques on his subjects, Harold Pinter very much took into account the oppressor' perspective. The focal point Pinter plays significantly in his socio-political perspective is exactly the objective of this perspective upon his narrative and characters: how dictatorship humiliates the human abilities to control and to understand life in their own way. When interviewed, Pinter explains that an oppressor is offended by the mere existence of his subjects, and not by a specific action that they carry out. He states that "there is no such thing as an offense, apart from the fact that everything is their very life is an offense, as far as the authorities go. Their very existence is an offense 
since that existence in some way or another poses critical

questions or is understand to do so"(Kane 2004, 42).

Inan (2000)states that Pinter's plays "reached beyond the world of the theatre and became part of the starkly politicized 1980s social and cultural scene. Above all, his work established a 'theory of power' and articulated the abuse of the political power of language. Pinter's work has obviously met the needs of the contemporary theatre"(19). For example, Pinter's One for the Road, Nicholas as a political power degrades his subjects (Victor, Gila, and Nicky), subjecting them to physical, psychological, and sexual oppression. This political genre seems to be running theme in Pinter's plays. Nonetheless, this one, in particular, serves as a textbook example of political oppression. Political suppression is shown in the in Pinter's One For the Road(1986) through unsettling ambiguity, and can be felt from the outset when Nicholas addresses Victor in the first scene by saying: "Hello! Good morning. How are you? Let's not beat about the bush. Anything but that. Daccord? You're a civilized man. So am I. Sit down."(Pinter 1986, 31). From the very outset of the play, when Nicholas is conversing Victor, the former abuses complete power over the latter. A further explanation from him regarding who is he ? or what his position? is not needed since his mere evasiveness terrifies his victim.

From the outset, the suppression is evident and is demonstrated through unsettling ambiguity. At the first scene of the One for the Road(1986), Nicholas asks: "What do you think this is? It's my finger. And this is my little finger in front of your eyes. Like this. And now I do the same with my little finger. I can also use both... at the same time. Like this. I can do absolutely anything I like. Do you think I'm mad? My mother did" (33). This portrays a sense of tension to the audience, and the purpose of using this tone is to make Victor feel fear, as well as the audience. In his interview, Pinter states that Nicholas "has all the power within those walls. He knows this is the case, he believes that it is right, for him, to possess this power because as far as he's concerned, he's acting for his country legitimately and properly. When he refers to the country's values, those are his values. And because of those values, he will kill; allow rape, everything he can think of. And torture"(Francis and Adler 2008, 144). This portrays Nicholas as a politician who completely understands and abuses his power, and will use it to exert control over his subjects.

Abd Sabur's Night Traveller (1995) is a small cast plays for three characters, namely the narrator, the passenger, and the conductor. The passenger is a man, who is oppressed by the Conductor. The Conductor is an oppres sor, resorting to the continual psychological trauma of the passenger. The conductor uses any means necessary to psychologically attack the passenger. Moreover, the Conductor, when introducing himself to the passenger, calls himself "Alexander the Great!" to be invasive and imposing on the passenger. At the same time, dramatic events are conveyed to the audience through the narrator. Sarhan(2017) states that the "History ,as a paper usually divorced, or usurped by such despots represented by the conductor, is a process in which both moral law and human identity are lost....it[history] becomes in Salih Abdel-Saboor's play a tool in the hand of the conductor dictator to dehumanize the common run of people"(87).

The play begins with the narrator setting the scene and describing the characters. The conductor appears suddenly in front of the passenger. He has a strong presence, and continually manipulates, degrades, and torments the passenger throughout the play. The latter is petrified of the conductor and is completely obedient to all demands. The conductor's oppressive behavior culminates in him killing the passenger on the grounds of a completely false accusation, namely that he killed a god and stole his identity. As the Night Traveller (1995) commences, the passenger portrays a feeling of worthlessness and hopelessness, offering his services as a slave for the conductor. $\mathrm{He}$ is in total belief that he has to serve his "Lord" (24). He vows to serve the conductor in order to save his life, and even begs and pleads for his life, however, the Conductor shows no mercy on him. Through such obsequious behavior, the passenger portrays himself as being inferior, which the conductor uses to his advantage.

The uncertainty of identity is a theme that runs throughout the play and is the very first is sue to think about. The audience has to witness the hero who does not win, or essentially the clown who provides. There are two types of suppression and violence that the passenger is subject to, namely the verbal language and the physical aggression carried out by the conductor, and which can be seen on stage. Double suppression is thus inflicted on the passenger, namely the suppression of the conductor, and the selfsuppression that he exerts on himself. The conductor employs the history to terrorize the passenger and the narrator describes the passenger as feeling 'feverish with fear, with a facial expression that changed like traffic lights. Constantly, Abd Saburimplies in his play the Night Traveller that the powerless of the people, encourage the imperial project to take away their power without showing resistance, 
However; In a case of disobedience of any character, this character will face psychic and physical exclusion to leave them in a state of hopeless despair of any way of political reform.

The Night Traveller narrator(1986) compares the story to Alexander the Great, orders his soldiers to move and that the passenger deals with a threat by surrendering without resistance. The passenger's submission shows his internal crisis, which ultimately leads to his demise and the following statement is obvious evidence to his submission: "Give me your orders, and I'll be quicker than your shadow" (26). The Conductor uses abused language to express his annoyanceby the Passenger's attendance. Moreover, the Conductor who has absolute power vanishes and destroys the Passenger's identification cards, (Abd Sabur 1995, 47).

The oppressors have a series of actions that they inflict upon the oppressed, and such practices have to be degrading and dehumanizing so that a high level of control can be achieved. These are known as external factors. In One for the Road, Nicholas demoralizes his victims in all sorts of ways, using psychological torture to crush their internal strength or desire to revolt. Physically, they are deprived of sleep, tortured and raped, with some eventually resorting to suicide. Nicholas does not believe that he should be remorseful or guilty for any of his actions. Likewise, in the Night Traveller, the Conductor claims to be different historical figures in order to manipulate the passenger and to control the latter's thoughts and logic. The suppress or does these things because he believes it will allow him to maintain order within the community and ultimately, preserve his own authority. Pinter states that the suppressor"knows this is the case, he believes this is right, for him, to possess this power, because, as far as he's concerned he's acting for his country's values, those are his values. In order to protect the realm, anything is justified. It is also, however, true that many of the natural sadistic qualities, which we all possess, are given free rein in the play" (Francis and Adler 2008, 144). The suppressor believes that he has a patriotic duty to do whatever it takes to uphold the status quo of the ruling system.

Successful oppressors must employ demeaning psychological tactics since they enable the oppressors to take away any guilt, responsibility or remorse from themselves for the victimization of individuals. Alice asserts that "Blaming the victims can be an important psychological strategy for violent and coercive individuals who were themselves victimized in the past. They are afraid of seeing that they were not responsible for the victimization they suffered; if they saw their past innocence clearly, they would have to experience the rage, grief, and humiliation they felt at being victimized" (Bushnell 1995, 51). She indicates that blaming the victim is a crucial tactic used by oppressors to exert power. With reference to his audience's response to the play, Pinter acknowledged the level of the shock and fear present in a majority of his audience. Nonetheless, he believed that this as much as fear of identifying with Nicholas and self-identification as an interrogator as it was a fear for the victims.

Despite the fact that Nicholas's occupation is never declared in the play, the audience can sense his air of political authority, since he tells his armed men to detain his victims. Pinter gives Nicholas character ambiguity, as his victims are never aware of his identity and position. However, his incredible knowledge of the lives and histories of his victims is evident. He knows the whole history of their family, including personal information about Gila's father. In the room, he is the primary figure of authority and control. Nicholas is the only person who seems to reveal important information regarding the characters to the audience.

In 2005, Pinter gave a Nobel Prize acceptance speech, in which he described Nicholas as being the epitome of a tyrannical politician. In this speech, he describes politicians are being powered hungry and more concerned with power than truth, and for this reason, they strive to uphold the state of ignorance amongst the people: "But as I have said, the search for the truth can never stop. It cannot be adjourned, it cannot be postponed. It has to be faced, right there, on the spot"(Billington 2009, 749).

It is evident here that Nicholas is a politician who thrives on the ignorance displayed by the oppressed since it allows him to possess complete power over what happens to them. On the whole, the knowledge-ignorance relationship between antagonist and protagonist is a running theme throughout Pinter's works. This allows for the creation of a dynamic enabling the antagonist to destroy the protagonist. Ruby Cohn questions the true identity of the characters in Pinter's plays, with the response being that "these nondescript villains and victims, acting out their drama in dilapidated rooms? Victims emerge from a vague past to go to their ineluctable destruction. Villains are messengers from the mysterious organization-- as in the works of Kafka or Beckett" (Ganz 1972, 78).

Likewise, the conductor uses his knowledge in opposition to render the passenger ignorant. He does not divulge his true identity to the pas senger or the audience until the very end. Instead, a variety of aliases and positions are 
used to define his identity, and this identity is continually changing. In the play, Alexander the great is a historical character that performs the conductor's role. He has all kinds of arms and tells the passenger what happens to man when he disobeys him: "Conductor: Forgive me! this has killed my dearest friend! I gave the rope to my friend, just to play with it you know"(Abd Sabur 1995, 31).

A mysterious setting like this, of which the passenger is part, allows the conductor to have full power and control. This ultimately creates a blindly obedient servant out of the passenger. There is a tragic irony in the play in that the dominating political party believes that by engaging in war and dissent and destroying individuality, it is carrying out God's will. As a result, Nicholas (an elitist) consistently makes arguments to justify the actions of the soldiers who kill, steal and ruin civilian homes and families based on pure hatred and callousness. He justifies the destroying of civilian homes and families as a means of upholding the political status quo. The sole purpose of referring to God is to subjugate them. Nicholas states that "God speaks through me"(1986) and consider himself as a pious man sent by heaven: (40). His relationship with the divine here automatically allows him to have full control over Victor. Similarly, the conductor in the Night Traveller claims to be related to the divine the left the helplessness of the everyday man, who resides in a mysterious and hostile world that he has no power to control, thus he cannot change his situation or defend himself from tyranny and abuse. He is simply waiting to die. In both plays, death is a major theme. In One for the Road, Nicholas(1986) states his love of death to Victor, indicating that he loves the death of others. To torture victor saying: "Death. Death. Death. Death. As has been noted by the most respected authorities, it is beautiful. The purest, most harmonious thing there is" (Pinter 1986, 45). The political significance of the play confirmed By repeating the word 'death' to repression the opponents(Victor).

\section{Comparing the Narratives of The Night traveller and The Birthday Party.}

The Night traveller's first Narrator refers to death when discussing the yellow coat of the conductor. He states that: "Some believe it is the color of glittering gold; others believe it is the color of sickness, of a swallow complexion, the color of death"(Abd Sabur 1995, 31). The conductor preys on his victim fear of dying in order to mentally destroys the latter. So, he refers to death to frighten him into becoming a submissive slave. He clearly indicates to the passenger the necessity of obeying every single order made by the conductor. "Passenger: Let me heat the water for your bath. Let me take care of your rosy towels. Let me carry your golden slippers around for you. But don't kill me... please!"'(Abd Sabur 1995, 25). Furthermore, as the play commences, the conductor displays his arsenal of weapons to inflict his power on the passenger(Abd Sabur 1995, 26). The Night traveller ends with the victim being executed and the conductorflaunting his arms in the face of the passenger, showing the passenger that he could be killed with any of the weapons(Abd Sabur 1995, 56). The hypothesis that the "colonist oppressor" will always show off his power to the victims of his self- suppression was previously made by Fanon.

Pinter attacks the abuse of language as a tool of integration, "Do the structures of language and the structures of reality move along parallel lines? Does reality essentially remain outside language, separate, obdurate, alien, not susceptible to the description? Is an accurate and vital correspondence between what is and our perception of it impossible? Or is it that we are obliged to use language in order to obscure and distort reality to distort what is, to distort what happens - because we fear it? We are encouraged to be cowards"(Rabey 2014, 58); Moreover, the verbal/nonverbal interaction of the characters in both plays shows certain evidence of oppression. Both Nicholas and the Conductor use language to create obedient slaves out of their victims, with both Victor and the passengerblindly obey orders. For instance, Nicholas(1986) boldly demands from Victor to be obedient, stating that:

\section{"VICTOR (quietly) \\ I don't know you. \\ NICHOLAS}

But you respect me.

VICTOR

\section{I don't know you.}

NICHOLAS

Are you saying you don't respect me?

Pause

Would you like to know me better?

VICTOR

What I would like ... has no bearing on the matter."

Likewise, the conductor also views the passenger as inferior by stating that "nobody dares disobey my orders, do you"(Abd Sabur 1995, 23). Both Nicholas and the conductor believe they must learn in quietness and full submis siveness. As far as verbal self- suppression is concerned, Fanon's theory of dehumanizing the oppressed should be discussed, 
particularly since he compares the "colonized" to animals. The oppressors in both works talk in a condescending manner to their subjects. Nicholas uses a degrading zoological term to address Gila "Fuckpig"(Pinter 1986, 65). The use of dehumanizing language from the antagonists to the protagonists in a majority of Pinter's works is a running theme. However, degrading language is used by the conductor to the passenger, "Why do you cower like a frightened mouse?"(Abd Sabur 1995, 25). The conductor, like all oppressors, resorts to dehumanizing language to make the passenger appear less human.

Likewise, through the use of non-verbal language (including pauses, postures, gesticulates, and costumes) (Nicholas and the conductor) as oppressors can effectively degrade the victims. The array of silent moments and pauses creates a sense of tension and also a power dynamic between the characters. The only pauses Nicholas makes are to pour a drink(Pinter 1986, 34-41). Similarly, the only pauses made by the conductor are to remove pieces of clothing. These pauses ultimately generate a sense of anticipation and tension that make the victims terrified. This ambiguity and evasiveness can ultimately cause the oppressed subjects to despise the way in which they are treated and could lead them to resist.

\section{CONCLUSION}

The plays of both Pinter and Abd Sabur have a lot in common, particularly in that they both convey the oppressors' abuse of power and a lack of knowledge that the oppressed possess. In literature and theatre, individuals in society viewed as being responsible for creating their own history and future, without being influenced by any hegemonic power. This means that the alternative of freedom would elitist domination of the masses, with the elitists enjoying the hopelessness and ignorance of the people. The works of both Pinter and Abd Sabur are absurdist, demonstrating oppression, injustice, ignorance, fear, and victimization. Such works have to be absurdist, and to do this they must employ undefined and individualized characters, an ambiguous setting, and unjustifiable plot developments.

Furthermore, a variety of vivid factors enhance the oppressive representations of the works. Nonetheless, the oppressive factor of ignorance is largely dominant in both plays. All protagonists in the place are in total oblivion, even as the end of the play. The antagonists, however, display much knowledge, particularly regarding their victims. As previously stated, Nicholas has full knowledge of the family he was interrogating, and likewise, the conductor was fully aware of the innocence and goodness of the passenger. He knew it was not possible that the passenger carried out the crime in question. Their knowledge of their victims' was not gained throughout the plot, but already known at the onset of the play. Furthermore, the protagonists in both plays had no need to use violence, since their subject hardly resisted. Consequently, their fate of death was ultimately determined by their submission, with the other characters remaining powerless.

Both of the plays critically bring to light different methods of oppression, in which the voices of both the victim and the dictator are heard. Both plays show understanding self- suppression is important, however, they also show subtextual solutions to the oppressive dynamic portrayed. In conclusion, it could be said that to counteract oppression, it is crucial to study and identify with the suppressor and to use the information to encourage people to act and to take a more active role in their communities. Moreover, given the inspirational nature of art, the transformation of such knowledge into a "conscious" theatrical performance could largely encourage oppressed masses to resist and revolt. Those who have the knowledge and determination could successfully resist oppressive rule and help their communities.

\section{REFERENCES}

[1] Abd Sabur, Salih (1995). Night Traveler. University Press.

[2] Billington, M. 2009. Harold Pinter. Faber \& Faber.

[3] Bushnell, Dana E. (1995). "Nagging” Questions: Feminist Ethics in Everyday Life. New Feminist Perspectives Series. Lanham, Md.: Rowman \& Littlefield.

[4] Francis, Gillen, and Thomas Adler, eds. (2008). Pinter Review, 2005-2008: Nobel Prize/Europe Theatre Prize Volume. Pinter Review.

[5] Ganz, A F (1972). Pinter: A Collection of Critical Essays. Twentieth Century Views. Prentice-Hall.

[6] Inan, Dilek (2000) . "The City and Landscapes Beyond Harold Pinter' s Rooms by A Thesis Submitted in Partial Fulfilment of the Requirements for the Degree of Doctor of Philosophy in English and Comparative Literary Studies University of Warwick, Department of English and Com." Comparative and General Pharmacology.

[7] Kane, Leslie (2004). "The Art of Crime: The Plays and Films of Harold Pinter and David Mamet."

[8] Kitishat, Dr. Amal Riyadh (2017). "Eliot's Thematic 
and Stylistic Influence on Salih Abdel-Saboor."

International Journal of Language andLiterature 4(2):

85-90.

[9] Pinter, Harold (1986). One for the Road. Grove Press.

[10] Prilleltensky, Isaac, and Lev Gonick(2007). "Polities Change, Oppression Remains: On the Psychology and Politics of Oppression." Political Psychology 17 (1): 127.

[11] Rabey, D I (2014). English Drama Since 1940. Longman Literature In English Series. Taylor \& Francis.

[12] Wendell, Susan (1990). “Oppression and Victimization; Choice and Responsibility." Hypatia 5 (3): $15-46$. 